\title{
Protein rRcovered from Oyster Wash Water by Ultrafiltration and Their Utilization as Oyster Sauce Through Fermentation
}

\author{
Chyuan-Yuan Shiau \\ Professor, Department of Food Science, National Taiwan Ocean University, Keelung, Taiwan, R.O.C \\ Tuu-jyi Chai \\ Professor, Department of Food Science, National Taiwan Ocean University, Keelung, Taiwan, R.O.C
}

Follow this and additional works at: https://jmstt.ntou.edu.tw/journal

Part of the Life Sciences Commons

\section{Recommended Citation}

Shiau, Chyuan-Yuan and Chai, Tuu-jyi (2009) "Protein rRcovered from Oyster Wash Water by Ultrafiltration and Their Utilization as Oyster Sauce Through Fermentation," Journal of Marine Science and Technology. Vol. 7: Iss. 2, Article 6. DOI: $10.51400 / 2709-6998.2529$

Available at: https://jmstt.ntou.edu.tw/journal/vol7/iss2/6

This Research Article is brought to you for free and open access by Journal of Marine Science and Technology. It has been accepted for inclusion in Journal of Marine Science and Technology by an authorized editor of Journal of Marine Science and Technology. 


\title{
PROTEIN RECOVERED FROM OYSTER WASH WATER BY ULTRAFILTRATION AND THEIR UTILIZATION AS OYSTER SAUCE THROUGH FERMENTATION
}

\author{
Chyuan-Yuan Shiau* and Tuu-jyi Chai*
}

Keywords: Oyster wash water, Protein, Ultrafiltration, Sauce.

\begin{abstract}
The use of ultrafiltration to recover proteins from oyster wash water was found to increase the protein concentration by 18 folds. The concentrations of total suspended solids and chemical oxygen demand in the permeate were reduced by 98 and $47 \%$, respectively. Fermentation was a good method to improve the flavor of the retentate from ultrafiltration. The increase in concentrations of extractive- $\mathrm{N}$, free amino acids and small peptides supported the idea that the fermentation process with Koji (cultured with Aspergillus oryzae) could accelerate the hydrolysis of the recovered protein. The Koji fermented juice was made into oyster sauce, which was accepted by the panel as being equivalent in quality to commercial oyster sauces. Recovery of proteins present in oyster wash water could be economically feasible in terms of their potential utilization, as well as the eventual reduction of organic matter in effluent disposal.
\end{abstract}

\section{INTRODUCTION}

Oyster stocks contain some liquid inside the shell, which is lost immediately after shucking. When freshly shucked oysters are exposed to fresh water, they may absorb substantial quantities of water and at the same time continue to bleed and thus lose more soluble solids $[1,2]$. Oysters are commonly processed by external washing, shucking, blowing (washing oyster meat in an aeration tank), draining, and packaging. The shucking process produces a large amount of wash water which is discarded as waste. This not only creates a pollution problem, but is also a resource waste.

Recovery of soluble solids from wash water for marketable byproducts and/or ingredients may generate additional revenue to oyster processors and also reduce organic matter in water to meet the requirements of effluent guidelines. Utilization of clam and oyster

Paper Received September 5, 1999. Revised October 28, 1999. Accepted November 22, 1999. Author for Correspondence: Chyuan-Yuan Shiau. *Professor, Department of Food Science, National Taiwan Ocean University, Keelung, Taiwan, R.O.C. processing effluent wastes has been accomplished. Commercial clam juice and dehydrated flavor ingredient have been prepared and characterized from clam processing waste water [3,4]. Shiau and Chai [5] used a steam-jacketed kettle to concentrate oyster shucking liquid waste for production of oyster soup. The membrane processes including ultrafiltration and reverse osmosis are simple concentration techniques with no heat treatment. They have been applied in food processing including dairy products, fruit juices, egg white, soy proteins, enzymes, and other materials $[6,7]$. Lin and Chiang [8] used a loose reverse osmosis membrane to recover flavor compounds from salted shrimp processing waste water.

Fish sauce is commonly used as a food condiment in Asian countries with about 400 million consumers [9]. Free amino acids have been implicated as being responsible for the characteristic taste of seafoods [10]. Several researchers reported that free amino acids were the most important contributor to the flavor of fish sauce $[9,11]$. The purpose of this study was to recover proteins from oyster wash water by ultrafiltration, to convert the recovered proteins into free amino acids through fermentation, and finally to process the fermented materials into oyster sauce.

\section{MATERIALS AND METHODS}

\section{Sample Collection}

Oyster (Crassostrea virginica) wash water was collected from a packing plant. The water samples were held in $20 \mathrm{~L}$ plastic carboys and stored in ice during transport to the laboratory. The samples were stored in a cold room $\left(4^{\circ} \mathrm{C}\right)$ for further processing and chemical analyses within $24 \mathrm{hr}$ after collection.

\section{Recovery of Protein by Ultrafiltration (UF)}

A Pellicon Cassette System (Millipore Corp., 
Bedford, MA; Model OM-141) was used to concentrate oyster wash water to the desired concentration. The solution that passed through the membrane was permeate, and the solution retained by membrane was retentate (concentrate). The concentrate stream was recirculated back to the initial solution. A commercial polysulfone membrane, PTGC (Millipore Corp.) with a 10,000 molecular weight cut-off (MWCO) was used. The total membrane processing area was $4,645 \mathrm{~cm}^{2}$. The process was operated at $10^{\circ} \mathrm{C}$ and 2.07 Bars (30 psi) pressure, and the initial flow rate was $2.7 \mathrm{~L} / \mathrm{min}$. For each experiment, $20 \mathrm{~L}$ wash water was concentrated to $1 \mathrm{~L}$ on a batch basis. It took $4.3 \mathrm{hr}$ to achieve concentration goal. At the end of each process, $0.5 \%$ Alconox $^{\mathrm{R}}$ detergent was used to clean the membrane at $35^{\circ} \mathrm{C}$ for 30 min. After completing the experiment, the membrane was thoroughly washed and stored in a $4 \%$ formaldehyde solution under refrigeration. The water quality indicators and chemical composition of the permeate and retentate were determined to compare with those of the initial feed water.

\section{Fermentation Process}

The UF retentate was mixed with $12 \%$ salt (w/w, raw material) and incubated at $25^{\circ} \mathrm{C}$ for fermentation with or without the addition of $2 \%$ Koji meal (rice inoculated with Aspergillus oryzae). Koji meal was provided by a soy sauce company in Taipei, Taiwan. The $\mathrm{pH}$ value, VB-N, extractive- $\mathrm{N}$, free amino acids and combined amino acids were analyzed during the 5month period of fermentation.

\section{Preparation of Oyster Sauce}

The UF retentate were fermented at $25^{\circ} \mathrm{C}$ for 3 months with rice Koji and then filtered through a standard No. 8 U.S. sieve $(2.38 \mathrm{~mm}$ openings $)$ and the filtrates mixed with sugar ( $8 \%$ of fermented juice), corn starch $(5 \%)$, wheat flour $(3 \%)$, monosodium glutamate $(0.1 \%)$ and caramel $(4 \%)$ to make oyster sauce. The mixture was packed into a $200 \mathrm{~mL}$ autoclavable bottle and retorted at $121^{\circ} \mathrm{C}, 1.05 \mathrm{~kg} / \mathrm{cm}^{2}$ (15 psi) for $15 \mathrm{~min}$. The chemical composition and sensory evaluation of final products $\mathrm{N}$ (without Koji) and $\mathrm{R}$ (sample with rice Koji) were analyzed and compared to 3 major representative commercial oyster sauces.

\section{Chemical Analyses}

\section{Proximate composition}

Moisture, lipid, ash, and salt were determined according to AOAC methods [12]. Total nitrogen was measured by the Kjeldahl method. Extractive-N was determined, after precipitating the proteins with $7 \%$ trichloroacetic acid, by the Kjeldahl method.

\section{Chemical indices}

The quality parameters of oyster liquors, including $\mathrm{pH}$ value, total solids, total suspended solids (TSS), and chemical oxygen demand (COD) were determined according to the standard procedures of USEPA [13]. Volatile basic nitrogen (VB-N) was measured using the microdiffusion technique of Conway [14].

\section{Free and combined amino acids}

The determinations of free and combined amino acids were according to the previous report [15]. The sample was homogenized for $2 \mathrm{~min}$ with the same volume of pre-cooled $14 \%$ trichloroacetic acid (TCA) to precipitate the proteins. The homogenate was centrifuged $(4000 \mathrm{x} \mathrm{g})$ at $4{ }^{\circ} \mathrm{C}$ for $10 \mathrm{~min}$ and the precipitate was extracted twice in the same way. An equal amount of ether was added to the extracted supernatant for removing TCA. This extraction was repeated successively 5 times. The aqueous solution was evaporated to dryness in a vacuum evaporator at a temperature below $40^{\circ} \mathrm{C}$ and then diluted with water for amino acids analysis. Amino acids were measured with a LKB 4150 automatic amino acid analyzer before and after hydrolysis of the extracts with $6 \mathrm{~N} \mathrm{HCl}$ at $110^{\circ} \mathrm{C}$ for $16 \mathrm{hr}$ in an evacuated sealed tube. Amino acids obtained without pre-hydrolysis of $\mathrm{HCl}$ were referred to as "free amino acids". The difference between the value of amino acids with $\mathrm{HCl}$ hydrolysis and free amino acids were referred to as "combined amino acids".

\section{Sensory Evaluation}

The sensory panel consisted of 6 Chinese restaurant chefs, 2 housewives and 2 University employees. They were familiar with the taste and aroma of oyster and oyster sauce. Two experimental oyster sauce products and 3 commercial products were evaluated for color, aroma, taste, oyster flavor intensity and overall acceptability according to the method used for sensory evaluation of clam juice [4]. Each panelist was presented with 5 product samples, each in a plastic cup in a random order. The samples were scored on a 7-point scale, with 1 designating "dislike very much", 7 being "like very much " for color, aroma, taste and overall acceptability. A 0-6 scale was used for rating oyster flavor intensity: $0=$ none at all, $1=$ just perceivable, $2=$ mild, $3=$ mild-distinct, $4=$ distinct, 5 $=$ distinct-strong, and $6=$ strong. 


\section{Statistical Analysis}

The results of sensory evaluation were analyzed for significance by analysis of variance (ANOVA) [16] and Duncan's multiple range test.

\section{RESULTS AND DISCUSSION}

\section{Clarification of Wash Water and Recovery of Proteins by Ultrafiltration}

Since the molecular weight of the major proteins in oyster wash water ranged from 20 to 28 KD [5], an ultrafiltration membrane with less than 20,000 molecular weight cut-off (MWCO) might be suitable for retaining these proteins. Therefore, a 10,000 MWCO membrane was selected for the UF process to recover proteins in wash water collected from the oyster packing plant. The volume of retentate after the UF process was $1 / 20$ of the initial volume of wash water.

The comparison of chemical changes in wash water before and after UF is shown in Table 1. As compared to the feed wash water, the concentrations of total suspended solids (TSS) and chemical oxygen demand (COD) in the permeate were reduced by 98 and $47 \%$, respectively. Reduction of the organic matter concentration in the permeate could reduce the treatment cost of waste effluent from oyster shucking plants. After the UF process, total solids were increased from 0.58 to $4.03 \%$ in the retentate and decreased to $0.38 \%$ in the permeate. The concentrations of protein- $\mathrm{N}$ and extractive- $\mathrm{N}$ in the retentate were 0.395 and $0.069 \%$, respectively. The proximate composition in the UF retentate was remarkably different from that of unconcentrated wash water. The content of crude protein (total- $\mathrm{N} \times 6.25$ ) accounted for $70 \%$ of total solids in the retentate, whereas only $3 \%$ was salt. About $26 \%$ and $39 \%$ of total solids were salt and crude protein in unconcentrated wash water, respectively.

Salt had the lowest recovery, indicating most salt would pass through the membrane into the permeate. The recovery of protein-N was $91.36 \%$, which was far greater than for other components. Since only about 8 . $6 \%$ of protein was lost in the permeate streams, the UF process with a 10,000 MWCO membrane was a good method for the recovery of proteins from oyster wash water. To utilize these recovered proteins, other processes employing fermentation were developed for the manufacture of oyster sauce.

\section{Fermentation of Recovered Proteins}

Fermentation with mold cultures has been reported to remove and mask unpleasant flavors and fish odor of
Table 1. Comparison of components in oyster wash water, UF retentate and permeate ${ }^{a}$

\begin{tabular}{lccc}
\hline Parameter & Wash water & Retentate $^{\mathrm{b}}$ & Permeate $^{\circ}$ \\
\hline pH value & 7.62 & 7.66 & 7.92 \\
Total solids (\%) & 0.58 & 4.03 & 0.38 \\
TSS (mg/L) & 403 & 4,683 & 10 \\
COD (mg/L) & 1,320 & 19,200 & 700 \\
VB-N (mg/100g) & 0.85 & 1.90 & 0.66 \\
Total-N (\%) & 0.036 & 0.464 & 0.012 \\
Extractive-N (\%) & 0.014 & 0.069 & 0.010 \\
Protein-N (\%) & 0.022 & 0.395 & 0.002 \\
Ash $(\%)$ & 0.21 & 0.29 & 0.19 \\
Salt $(\%)$ & 0.15 & 0.13 & 0.15 \\
\hline
\end{tabular}

${ }^{a}$ With a 10,000 MWCO membrane.

${ }^{\mathrm{b}}$ Retentate is $1 / 20$ of the original volume.

${ }^{\mathrm{c}}$ The difference of total-N and extractive-N.

enzymatic protein hydrolysates of aquatic source foods [17]. This study employed Aspergillus oryzae for fermentation; this organism is widely employed in food industry for various fermentations. It produces proteolytic and amylolytic enzymes $[18,19]$ and has advantages over many other microbial fermentation organisms.

To find the optimal salt concentration to prevent spoilage of the fermentation mixture, salt concentrations ranging from 0 to $16 \%$ were added to the retentate and incubated for 12 days. The results (data not shown) indicated that $12 \%$ salt prevented spoilage of the products during fermentation. Therefore, $12 \%$ salt was added to the UF retentate which was incubated at $25^{\circ} \mathrm{C}$ with and without the addition of $2 \%$ Koji for fermentation. Koji has been used for producing soy sauce and fermented soybean pastes (miso) in oriental countries for a long time [20].

\section{Changes in pH Value, VB-N and Extractive-N during Fermentation}

The $\mathrm{pH}$ value was sharply decreased in the early stage of fermentation and then gradually decreased after the first month of fermentation (Fig. 1). Some acids might be produced in the fermentation process resulting in the drop of $\mathrm{pH}$ value. Volatile acids such as acetic, propionic, butyric, valeric and lactic acid have been identified in fish sauce [21]. The drop degree of $\mathrm{pH}$ value in the rice Koji sample was found higher than the control treatment. VB-N gradually increased in the samples during fermentation (Fig. 1) and increased with time. The increase in $\mathrm{pH}$ value of the Koji sample might be due to the increase in VB-N. The extractive-N increased as fermentation progressed, suggesting that 

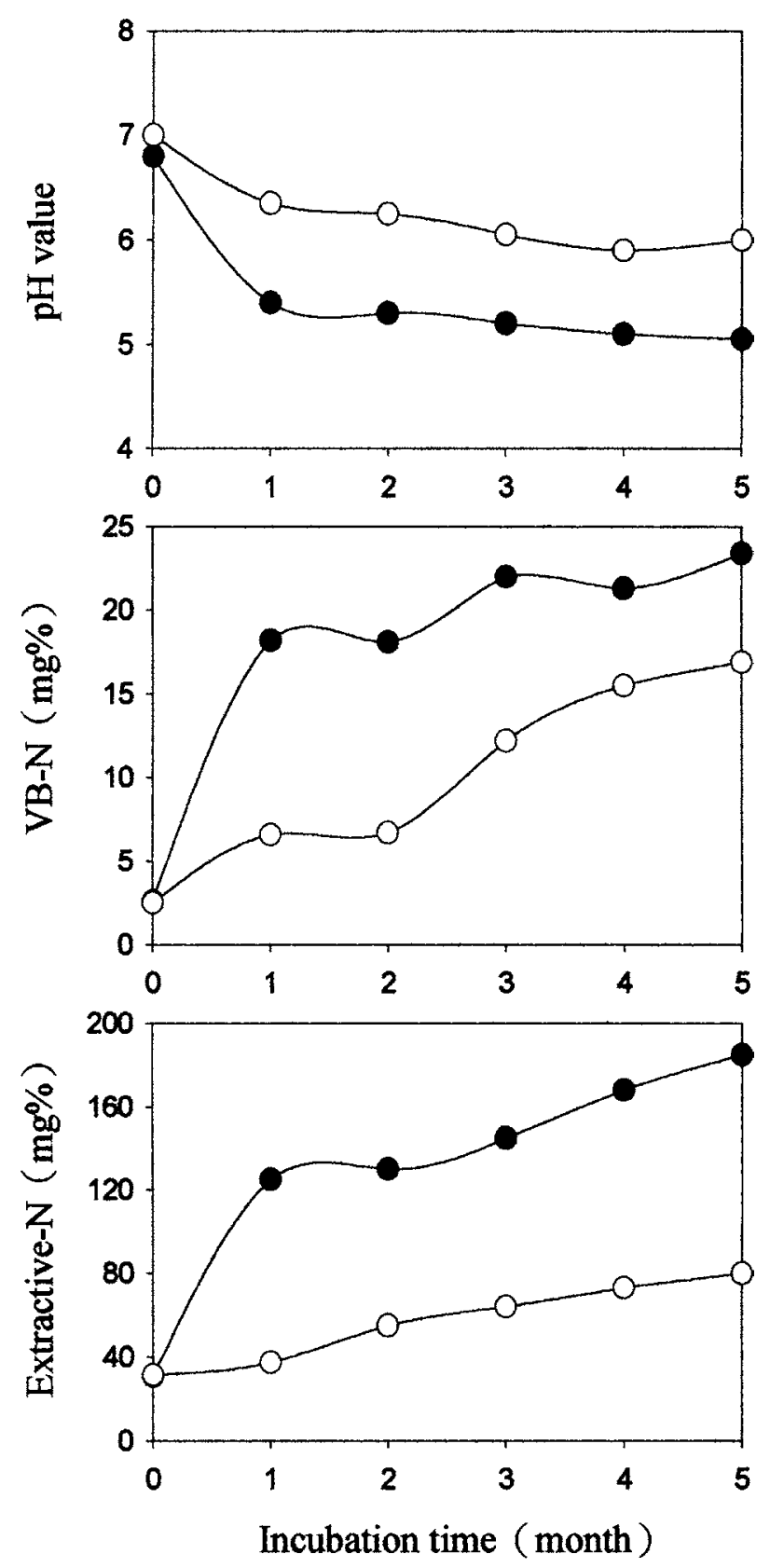

Fig. 1. Changes of $\mathrm{pH}$ value, VB-N and extractive-N in UF retentate with the addition of rice koji during fermentation at $25^{\circ} \mathrm{C}$. $\ominus$, control group; - , with koji.

proteins were hydrolyzed by enzymes into extractive nitrogenous compounds. A higher level of extractive-N was found in Koji sample. The addition of Koji to the UF retentate apparently accelerated protein hydrolysis as compared to the control sample.

The changes in $\mathrm{pH}$ value, VB-N and extractive-N during the course of fermentation indicated that the rate of protein hydrolysis of the UF retentate with addition of Koji was faster than that without Koji. Apparently, fermentation with Koji could reduce the processing time. A rapid increase in protein digestion in the early fermentation stage was observed, and the rate decreased after the first month incubation. The Koji enzymes might have been inhibited by end products of the fermentation process, resulting in reduction of enzyme activity after prolonged incubation.

\section{Changes in Free and Combined Amino Acids during Fermentation}

The changes of the profile and quantity of free amino acids (FAA) after fermentation are shown in Table 2. The FAA profile of the UF retentate was similar to that of wash water [2]. The predominant FAA were taurine, alanine, glutamic acid, glycine and $\beta$ alanine. The profile and quantity of FAA in the retentate showed no remarkable difference from those of two non-fermented samples. The FAA originated from Koji resulted in a higher level of the total FAA in Koji sample than that in natural sample without Koji.

The total amount of FAA increased after fermentation. In natural sample the total FAA increased from 57 to $250 \mathrm{mg} / 100 \mathrm{~g}$ after 3 months fermentation. In Koji fermented product, the total FAA content was $841 \mathrm{mg} / 100 \mathrm{~g}$, which was 12 times higher than nonfermented sample. The magnitude of FAA increase in the Koji fermented product was 3.4 times higher than that of natural sample, indicating that the fermentation process with Koji accelerated the hydrolysis of proteins resulting in an increase of FAA.

The FAA profile also had a great change after fermentation. As compared to the non-fermented sample, the concentration of all individual FAA except taurine significantly increased in both fermented products. Taurine was not a constituent amino acid of protein [22], and therefore, the hydrolysis of protein would not produce taurine. Aspartic acid, threonine, valine, leucine, isoleucine and phenylalanine, the minor FAA in the retenttate, had a higher rate of increase after fermentation than glutamic acid, glycine, alanine, $\beta$ alanine and ornithine, the major FAA in the retentate. The increased concentrations of $\beta$-alanine and ornithine were much lower than those of other FAA. Methionine and tyrosine, not detected in the non-fermented samples, were found in the fermented products.

Combined amino acids (CAA) were proposed as amino acid constituents of small molecular peptides [23]. Table 3 shows changes in CAA after fermentation. Like FAA, CAA in Koji sample was higher than that in natural sample. The CAA profile of retentate was different from that of wash water. The predominant CAA in wash water were glutamic acid, glycine, and alanine, which together accounted for $54 \%$ of the total 
Table 2. Changes in free amino acids $(\mathrm{mg} / \mathbf{1 0 0 g})$ of UF retentate before and after fermentation at $25^{\circ} \mathrm{C}$

\begin{tabular}{lccccc}
\hline Amino acid & \multirow{2}{*}{ Retentate } & \multicolumn{2}{c}{ Natural $^{\mathrm{a}}$} & \multicolumn{2}{c}{ Koji $^{\mathrm{b}}$} \\
\cline { 3 - 6 } & & 0-Time & 3-Month & 0-Time & 3-Month \\
\hline Taurine & 20.74 & 18.21 & 17.29 & 16.94 & 14.88 \\
Aspartic acid & 2.45 & 2.21 & 24.39 & 3.56 & 98.55 \\
Threonine & 0.69 & 1.01 & 10.43 & 2.00 & 41.08 \\
Serine & 1.01 & 0.99 & 1.72 & 1.90 & 33.60 \\
Glutamic acid & 8.76 & 7.96 & 41.75 & 9.83 & 130.52 \\
Glutamine & - & - & - & - & - \\
Proline & 2.58 & 2.30 & 15.26 & 3.28 & 27.28 \\
Glycine & 3.72 & 3.08 & 14.04 & 3.58 & 34.69 \\
Alanine & 8.58 & 7.64 & 21.20 & 7.49 & 57.38 \\
Valine & 0.63 & 0.71 & 13.52 & 2.17 & 51.73 \\
Methionine & - & - & 2.55 & - & 0.45 \\
Isoleucine & 0.45 & 0.49 & 11.91 & 1.80 & 43.56 \\
Leucine & 0.44 & 0.66 & 18.36 & 2.37 & 64.54 \\
Tyrosine & - & - & 1.88 & - & 35.86 \\
Phenylalanine & 0.38 & 0.61 & 9.47 & 1.50 & 38.55 \\
$\beta$-alanine & 3.02 & 3.78 & 4.48 & 3.51 & 6.86 \\
Ornithine & 2.71 & 2.69 & 13.05 & 2.93 & 24.23 \\
Lysine & 2.45 & 2.57 & 21.22 & 2.42 & 54.26 \\
Histidine & 0.80 & 0.81 & 4.67 & 0.97 & 21.36 \\
Arginine & 1.86 & 1.70 & 2.22 & 2.04 & 50.61 \\
Total & 61.24 & 57.42 & 249.51 & 68.29 & 840.99 \\
\hline Ultrenyyyyy & & & & &
\end{tabular}

${ }^{a}$ Ultrafiltrated retentate contained $12 \% \mathrm{NaCl}$.

${ }^{\mathrm{b}}$ Retentate contained $12 \% \mathrm{NaCl}$ and $2 \%$ rice Koji.

${ }^{\mathrm{c}}$ Not detectable or trace.

CAA. However, these CAA found in the retentate only accounted for $37 \%$. This indicated that the ultrafiltration process changed the CAA profile of wash water. In addition, the ratio of CAA to the sum of CAA and FAA in the retentate was much higher than that of wash water, showing that the retentate consisted of a higher proportion of peptide amino acids after the ultrafiltration process.

CAA increased after fermentation, but the rate of increase was lower than that for FAA. The total amount of FAA in the Koji fermented product was 2.5 times higher than that of the natural fermented product. The increases in concentration of aspartic acid, leucine, isoleucine, lysine, and histidine were the only compounds with decreased levels after fermentation.

\section{Quality of Oyster Sauce Products}

The chemical composition of two experimental oyster sauces and three commercial products are shown in Table 4. The composition of different commercial products was varied. The moisture content ranged from 40.32 to $75.47 \%$, crude protein from 2.25 to $13.13 \%$,
Table 3. Changes in combined amino acids $(\mathrm{mg} / \mathbf{1 0 0} \mathrm{g})$ of UF retentate before and after fermentation at $25^{\circ} \mathrm{C}$

\begin{tabular}{lccccc}
\hline Amino acid & \multirow{2}{*}{ Retentate } & \multicolumn{2}{c}{ Natural $^{\mathrm{a}}$} & \multicolumn{2}{c}{ Koji $^{\mathrm{b}}$} \\
\cline { 3 - 6 } & & 0-Time & 3-Month & 0-Time & 3-Month \\
\hline Taurine & $-^{\mathrm{c}}$ & - & - & - & - \\
Aspartic acid & 5.23 & 4.71 & 5.99 & 4.18 & 21.03 \\
Threonine & 3.35 & 2.47 & 4.30 & 2.27 & 9.18 \\
Serine & 2.12 & 2.32 & 1.96 & 2.06 & 7.04 \\
Glutamic acid & 7.51 & 6.82 & 11.87 & 6.95 & 14.87 \\
Glutamine & - & - & - & - & - \\
Proline & 0.88 & - & 0.07 & 2.06 & - \\
Glycine & 3.34 & 3.10 & 6.50 & 3.69 & 17.52 \\
Alanine & 1.64 & 1.52 & 3.73 & 1.46 & 1.55 \\
Valine & 1.31 & 1.20 & 2.57 & 1.40 & 8.42 \\
Isoleucine & 0.77 & 0.95 & 2.00 & 1.15 & 6.22 \\
Leucine & 1.51 & 1.26 & 1.90 & 1.26 & 8.33 \\
Phenylalanine & - & - & 5.91 & - & 2.47 \\
$\beta$-alanine & 0.85 & 0.86 & 1.89 & 0.82 & 1.35 \\
Ornithine & 0.92 & 0.88 & 1.72 & 0.93 & 1.91 \\
Lysine & 1.41 & 1.61 & 2.26 & 1.19 & 12.86 \\
Histidine & 1.26 & 1.22 & 0.97 & 0.93 & 8.53 \\
Arginine & 1.55 & 1.41 & - & 2.91 & - \\
Total & 33.65 & 30.03 & 53.64 & 33.26 & 121.28 \\
\hline
\end{tabular}

${ }^{a}$ Ultrafiltrated retentate contained $12 \% \mathrm{NaCl}$.

${ }^{\mathrm{b}}$ Retentate contained $12 \% \mathrm{NaCl}$ and $2 \%$ rice Koji.

${ }^{\mathrm{c}}$ Not detectable or trace.

and salt from 4.82 to $10.36 \%$. The great variation in the production of oyster sauce had a variety of procedures and added ingredients.

The levels of total-N [24] and extractive-N [21] have been used as the quality indices for fish sauce. The experimental products $\mathrm{N}$ and $\mathrm{R}$ had a lower level of total- $\mathrm{N}$ than the commercial products $\mathrm{C} 2$ and $\mathrm{C} 3$, but higher than $\mathrm{C} 1$. The extractive- $\mathrm{N}$ in commercial products was also higher than that of experimental products. It is common practice for oyster sauce manufacturers to add artificial flavor enhancers such as MSG to their products, so that a higher level of extractive- $\mathrm{N}$ would be found in the products. The level of VB-N in 5 samples ranging from 11.78 to $28.54 \mathrm{mg} / 100 \mathrm{~g}$, was much lower than that of other fermented seafood products, which usually contain a very high level of VB-N [21].

All samples had higher salt content than that of common foods. A high concentration of salt was added to oyster sauce to inhibit the growth of microorganisms during processing and storage [10,21]. In addition, preservatives, such as sodium benzoate as shown on the label, were present in commercial products.

Sensory evaluation data for 2 experimental oyster sauces $(\mathrm{N}$ and $\mathrm{R})$ and 3 commercial products $(\mathrm{C} 1, \mathrm{C} 2$ and C3) from 10 panelists are shown in Table 5. Signifi- 
Table 5. Sensory evaluation of oyster sauce products

\begin{tabular}{lccccc}
\hline Attribute & $\mathrm{C} 1^{*}$ & $\mathrm{C} 2$ & $\mathrm{C} 3$ & $\mathrm{~N}$ & $\mathrm{R}$ \\
\hline Color & $5.30 \pm 1.16^{\mathrm{a}}$ & $5.60 \pm 0.97^{\mathrm{a}}$ & $6.20 \pm 1.14^{\mathrm{a}}$ & $5.00 \pm 0.82^{\mathrm{b}}$ & $5.40 \pm 0.07^{\mathrm{a}}$ \\
Aroma & $4.90 \pm 1.73^{\mathrm{b}}$ & $5.00 \pm 1.16^{\mathrm{b}}$ & $6.10 \pm 1.45^{\mathrm{a}}$ & $3.50 \pm 0.97^{\mathrm{c}}$ & $4.60 \pm 1.08^{\mathrm{b}}$ \\
Taste & $4.60 \pm 1.78^{\mathrm{b}}$ & $5.30 \pm 1.57^{\mathrm{b}}$ & $6.20 \pm 0.92^{\mathrm{a}}$ & $4.10 \pm 1.73^{\mathrm{b}}$ & $4.20 \pm 1.03^{\mathrm{b}}$ \\
Oyster flavor intensity & $4.50 \pm 0.86^{\mathrm{b}}$ & $5.60 \pm 1.22^{\mathrm{a}}$ & $4.60 \pm 1.12^{\mathrm{b}}$ & $4.70 \pm 1.14^{\mathrm{b}}$ & $4.20 \pm 1.06^{\mathrm{b}}$ \\
Overall acceptability & $4.70 \pm 1.77^{\mathrm{bc}}$ & $5.40 \pm 1.27^{\mathrm{b}}$ & $6.50 \pm 0.71^{\mathrm{a}}$ & $4.10 \pm 1.26^{\mathrm{c}}$ & $4.50 \pm 1.18^{\mathrm{bc}}$ \\
\hline
\end{tabular}

* C1-C3 were commercial oyster sauces. Experimental products were made from 3-month fermented UF retentate: N, without Koji; R, with rice Koji.

a-c Sensory scores means with the same superscript letter in a row did not vary significantly $(\mathrm{p}>0.05)$ from each other $(\mathrm{n}=10$ panelists). Hedonic scale $=7$, "like very much", and 1, "dislike very much". For oyster flavor intensity, 0 , none at all, and 6 , strong.

Table 4. Chemical composition of oyster sauce products

\begin{tabular}{lrrrrr}
\hline & \multicolumn{1}{c}{$\mathrm{C}^{\mathrm{a}}$} & \multicolumn{1}{c}{$\mathrm{C} 2$} & \multicolumn{1}{c}{$\mathrm{C} 3$} & \multicolumn{1}{c}{$\mathrm{N}^{\mathrm{b}}$} & \multicolumn{1}{c}{$\mathrm{R}$} \\
\hline pH value & 4.99 & 4.56 & 5.20 & 5.31 & 4.82 \\
Moisture (\%) & 67.46 & 75.47 & 40.32 & 69.68 & 69.21 \\
Total-N (\%) & 0.36 & 2.10 & 1.52 & 0.37 & 0.42 \\
Extractive-N (\%) & 0.23 & 1.05 & 1.29 & 0.07 & 0.15 \\
Lipid (\%) & 0.53 & 4.29 & 2.15 & $-^{\mathrm{c}}$ & \multicolumn{1}{c}{-} \\
Ash (\%) & 10.11 & 5.60 & 11.94 & 9.99 & 10.10 \\
Salt (\%) & 9.28 & 4.82 & 7.91 & 9.15 & 9.46 \\
VB-N (mg/100g) & 24.20 & 28.42 & 14.70 & 11.78 & 19.27 \\
\hline
\end{tabular}

${ }^{a} \mathrm{C} 1-\mathrm{C} 3$ are commercial oyster sauces.

${ }^{\mathrm{b}}$ Experimental products were made from ultrafiltrated retentate fermented at $25^{\circ} \mathrm{C}$ for 3 months without Koji (N) and with rice $\mathrm{Koji}(\mathrm{R})$.

${ }^{\mathrm{c}}$ Not determined.

cant difference $(\mathrm{p}<0.05)$ was found in color, aroma, taste and acceptability. On the other hand, experimental product $\mathrm{N}$ was rated lowest. Although product $\mathrm{C} 2$ contained more protein than $\mathrm{C} 3$ (Table 4 ), its sensory score was lower than $\mathrm{C} 3$. However, extractive- $\mathrm{N}$ in product C3 was higher than C2. This might be the reason why product $\mathrm{C} 3$ was more acceptable than $\mathrm{C} 2$. No significant difference $(p>0.05)$ of color, aroma, taste and overall acceptability was found between product R, C1 and $\mathrm{C} 2$, indicating that the experimental products made from the Koji fermented oyster wash water could be accepted by the panelists as commercial oyster sauces.

\section{REFERENCES}

1. Figger, E.A., Novak, A.F., and Burnett, W.T., "Tritiated Water for Measuring Fluid Transfer in Oysters," Food Technol., Vol. 16, No. 1, pp. 112-114 (1962).

2. Shiau, C.Y. and Chai, T., "Extractive Nitrogenous Components of Oysters (Crassostrea virginica) and Their Released Liquors," J. Fish Soc. Taiwan, Vol. 21, No. 3, pp. 281-291 (1994).
3. Burnettet, J.A., Flick, G.J., Miles, J.R., Ory, R.L., Angelo, A.J.S., and Dupuy, H.P., "Characterization and Utilization of Ocean Quahog (Arctica islandica) Clam Juice as a Liquid and Dehydrated Flavoring Agent," J. Food Sci., Vol. 48, pp. 353-356 (1983).

4. Reddy, N.R., Flick, G.J., Dupuy, H.P., and Boardman, G.D., "Characterization and Utilization of Dehydrated Wash Waters from Clam Processing Plants as Flavoring Agents," J. Food Sci., Vol. 54, pp. 55-59 (1989).

5. Shiau, C.Y. and Chai, T., "Characterization of Oyster Shucking Liquid Wastes and Their Utilization as Oyster Soup," J. Food Sci., Vol. 55, pp. 374-378 (1990).

6. Cheryan, M., Ultrafiltration Handbook, Technomic Publishing Co. Inc., Lancaster, PA (1986).

7. Chiang, B.H. and Pan, W.D., "Membrane Separation Technology and Its Application in Food Processing," Proceeding National Sci. Council, Vol. 13, pp. 211-226 (1989).

8. Lin, C.Y. and Chiang, B.H., "Desalting and Recovery of Flavour Compounds from Salted Shrimp Processing Waste Water by Membrane Process," Int. J. Food Sci. Technol., Vol. 28, pp. 453-460 (1993).

9. Ohta, S., "Fish Sauce," New Food Ind., Vol. 31, No. 12, pp. 36-42 (1989).

10. Fuke, S., "Taste-Active Components of Seafoods with Special Reference to Umami Taste," Seafoods: Chemistry, Processing Technology and Quality, Blackie Academic \& Professional, Glasgow, UK, pp. 115-139 (1994).

11. Huynh, M.D., "Fish Sauce Product through Fermentation: A Method to Utilize Fishery Waste," Technical Report No. 8, B.C. Research, Vancouver, Canada (1982).

12. AOAC, Official Methods of Analysis, $15^{\text {th }}$ ed., Association of Official Analytical Chemists, Arlington, VA (1990).

13. USEPA, Methods for Chemical Analysis of Water and Wastes, U.S. Environmental Protection Agency, Cincinnati, OH (1990).

14. Cobb, B.F., Aoaniz, I., and Thomson, C.A., "Biochemi- 
cal and Microbial Studies on Shrimp: Volatile Nitrogen and Amino Acid Analysis," J. Food Sci., Vol. 38, pp. 431-437 (1973).

15. Shiau, C.Y., Chai, T., and Chiou, T.K., "NitrogenContaining Taste Components of Oyster Wash Water and Changes in Quantities during Heat Concentration," J. Aquatic Food Product Technol., Vol. 4, No. 3, pp. 7588 (1995).

16. SAS, SAS User's Guide: Basic Statistical Analysis, SAS Institute, Cary, NC (1988).

17. Hossain, M.A., Furuichi, M., and Yone, Y., "POV, TBA, and VBN Values, and Proximate, Amino Acids, and Fatty Acid Compositions of Scrap Meals Fermented with Fungi," Nippon Suisan Gakkaishi, Vol. 53, pp. 1629-1633 (1987).

18. Cruz, R. and Park, Y.K., "Production of Fungal $\alpha$ Galactosidase and Its Application to Hydrolysis of Galactooligosaccharides in Soybean Milk," J. Food Sci., Vol. 47, pp. 1973-1977 (1982).

19. Harayma, F. and Yasuhira, H., "Comparison of Hydrolytic Action on Soybean Protein by the Genus Aspergillus and Those of Rhizopus," J. Brew. Soc. Sci. Fish., Vol. 48, pp. 65-71 (1989).

20. Nikkuni, S., Okada, N., and Itoh, H., "Effect of Soybean Cooking Temperature on the Texture and Protein Digestibility of Miso," J. Food Sci., Vol. 53, pp. 445-449 (1988).

21. Liston, J. and Dollar, A.M., "Microbiology and Chemistry of Fermented Fish," J. Food Sci., Vol. 31, pp. 105109 (1966).
22. Hayes, K.C., "A Review on the Biological Function of Taurine," Nutr. Rev., Vol. 34, No. 6, pp. 161-165 (1976).

23. Konosu, S., Yamaguchi, K., and Hayashi, T., "Roll of Extractive Components of Boiled Crab in Producing the Characteristic Flavor," Umami: A Basic Taste, Marcel Dekker, Inc., New York, pp. 235-253 (1987).

24. Subba Rao, G.N., Fisheries Products Manual, FAO Regional Office for Asia and Far East, Bankok, Tailand (1961).

\section{超過滤回收牡螗水洗液蛋白質經由 發酵製成蠔油}

$$
\text { 蕭泉源蔡土及 }
$$

國立臺灣海洋大學食品科學系

$$
\text { 摘 要 }
$$

利用超過滤回收牡蜼水洗液之蛋白質濃度增爲 18倍, 過滤汁液之懸浮固體與化學需氧量則分別減少 98\%和 $47 \%$ 。發酵法可改善超過滤濃縮物之風味, 經 接種Aspergillus oryzae之米䴯發酵後, 回收之蛋白質 分解産生大量之含氮抽出物成分、游離胺基酸與小分 子胜肽。發酵液經製成之蠔油, 其接受性與市售商品 比較並無影著差異, 可知牡蝺汁液蛋白質之回收利用 具潛力, 且可減少排放水之有機物量。 